\title{
The morendo of the Anthropocene
}

\section{Vincent Blok ${ }^{1}$}

Accepted: 11 December 2020 / Published online: 2 June 2021

(c) The Author(s) 2021

\begin{abstract}
This essay engages with Bernard Stiegler's discussion with Martin Heidegger in The ordeal of Truth, published in Foundations of Science 2020 (this volume). It appreciates Stiegler's progressive reading of Heidegger's work but critically reflects on several elements in his work. A first element is the methodological aspect of Heidegger's being historical thinking, which is missed by Stiegler and confirms the indifference towards philosophical method that can be found in the work of many contemporary philosophers. A second element concerns Heidegger's and Stiegler's remaining humanism and the necessity to move beyond humanism and post-humanism in the era of global warming. A third element of reflection concerns Stiegler's idea of the obligation of making our being-in-default come true, which shows a hidden metaphysical orientation in his work.
\end{abstract}

Keywords Stiegler $\cdot$ Heidegger $\cdot$ Cotard syndrom $\cdot$ Entropy $\cdot$ Truth

The starting point of The ordeal of Truth is found in Stiegler's initial discomfort with Heidegger's opposition between Sorge and Besorgen, Eigentlichkeit and Uneigentlichkeit, Wahrheit and Richtigkeit, which degrades the initial positive notion of the existential technicity of human Dasein in Being and Time to a negative notion of technology as Gestell in his later being historical thinking. He is now critical about his own initial assessment of Heidegger's notion of Gestell from this oppositional perspective, because it misses the point that according to Heidegger, the essence of technology is ambiguous; this ambiguity of Gestell does not involve its danger within which the saving power grows, which may be read as a prefiguration of Stiegler's pharmacology, but the experience of the inaccessibility of Ereignis.

This ambiguity can already be found in Being and Time. While-especially Frenchreaders of Being and Time didn't cease to read his efforts as a call to move from Uneigentlichkeit to Eigentlichkeit, the ambiguity of Eigentlichkeit consists in its inaccessibility. Only in our experience of Un-eigenlichkeit, a negative experience of Eigentlichkeit is possible. On the one hand, because human Dasein is included in the tendency to fall (Abfall),

This comment refers to the article available at https://doi.org/10.1007/s10699-020-09736-3.

Vincent Blok

vincent.blok@wur.nl

1 Philosophy Group, Wageningen University, Wageningen, The Netherlands 
Eigentlichkeit can only be achieved within the tendency of Uneigentlichkeit. On the other hand, to the extent that the experience of Eigentlichkeit is dependent on Uneigenlichkeit as its condition, Eigentlichkeit is never achieved and remains inaccessible.

With this, it becomes clear why Heidegger is primarily a methodological thinker, as I have argued in Heidegger's concept of philosophical method. He does not presuppose the a priori accessibility of notions like Sorge, Eigentlichkeit and Wahrheit and renders the question concerning access the central philosophical problem. Considering the methodological aspects of Heidegger's being historical thinking is important if Stiegler in his article wants to move beyond his initial oppositional perspective in order to ask for Ereignis as the hidden and wants to engage in an ordeal of truth. But he nowhere in the article discusses the methodological problem of the inaccessibility of Ereignis, and how he as a philosopher is able to have access to this inaccessible phenomenon. Instead of addressing the methodological question of how we can make any legitimate claim about Ereignis as the hidden, he uncritically subscribes to a position that it is "only with the introduction into modern physics ... that it becomes possible to think (that is, to take care of [panser]) Ereignis as the destiny of Gestell" (5). This is not a personal omission of Stiegler's work, but confirms the indifference towards philosophical method that can be found in the work of many contemporary philosophers, ranging from Morton to Harman. It indicates the crisis of contemporary philosophy (Blok 2020a).

Instead of uncritically subscribing to scientism, or to a position that understands itself in terms of taking care (panser), the in-accessibility of Ereignis indicates that it is a phenomenon that we can never take care of, always withdraws from our efforts to take care, and calls for a consideration of the philosophical method before we engage in any ordeal of truth.

\section{II}

Stiegler argues that Heidegger's notion of Gestell enables us to think the Anthropocene. What Heidegger ignores in his proto-philosophy of the Anthropocene, according to Stiegler, is the question of entropy and negentropy. Stiegler's connection between the Anthropocene and the notions of entropy and negentropy enables us to reflect on Earth and World in the Anthropocene. We can argue that entropy and negentropy emerge already in Heidegger's concept of the truth of being as double movement of concealing-unconcealing, namely as the coming forth or rising up of a World in which we are at home, its endurance, and finally its decay in its inclination towards the concealment and self-closedness of Earth from which the World arose. Earth and World are essentially different and at the same time not separated from each other, that is, they are performatively constituted in the strive between negentropy or unconcealing (World) and entropy or concealing (Earth) of the truth of being. Although we have to nuance Stiegler's criticism therefore, because Heidegger provides in fact a proto-conceptualization of entropy and negentropy, we may argue that Stiegler is also right in a way. The entropic movement of concealing remains in the end unthought in Heidegger's work because he conceptualizes Earth from the perspective of the World. This is however not a personal omission of Heidegger. Philosophers never thought about the Earth as the extra-ordinary and always thought Earth out of World, matter out of form etc. (Blok 2019).

Be it as it may, Stiegler's criticism enables us to ask for the role of negentropy or unconcealing of World in the Anthropocene. While post-humanists like Timothy Morton reject 
any notion of World in the Anthropocene in favour of the enmeshment of human technicity in the natural environment, we argued elsewhere that only the notion of World enables us to understand the meaning of our being-in-the-Anthropocene in contrast with our being-inthe-Holocene (Blok 2020b). We can read Stiegler's "process of the exosomatization of the functions and faculties of noesis" as a process of World-constitution, in which the World that articulates our being-in-the-Anthropocene is both constitutive and destitutive for contemporary noesis. What is constituted in this exosomatic process is however not only the world of global warming in the third phase of the Anthropocene, which is indicated by Heidegger's Gestell, but the neganthropy of Earth beyond humanism and post-humanism, which is indeed absent in Heidegger's thought.

The singularity of the experience of global warming that we face today is that it draws our attention to Earth as ontic-ontological condition of our being-in-the-Anthropocene. The emergence of planet Earth in Earth's history is a prerequisite not only for the emergence of human being on Earth at an ontic level, but more important, also for humans' responsiveness to the world around us, that is, for our being-in-the-world at an ontological level. In the Earth's history, Earth was long before humans emerged on the planet and, in this respect, our being-in-the-world emerges, unfolds, and expands out of Earth in the era of humanity and threatens to go back into Earth again at the end of this era in which humanity is threatened by global warming (Blok 2019). It is the experience of Earth as ontic-ontological condition of the possibility of our being-in-the-world in the era of global warming that confronts us with the Anthropocene on the one hand, and raises questions regarding the ordeal of truth on the other. My hypothesis is that a post-Heideggerian conception of the strive between negentropy or unconcealing (World) and entropy or concealing (Earth) can inform such an ordeal beyond scientism.

\section{III}

Although this ordeal of truth cannot consist in any form of taking care as we have seen, Stiegler's conceptualization of being-in-the-world as being-in-default, which I would frame as being-in-the-world as being-on-Earth, may be of help here. But in order to make sense, we have to criticize the remainder of the humanistic orientation of Stiegler's example of Joë Bousquet, and to reframe the human wound beyond humanism and post-humanism. The wound that we bear today is not a personal wound that we bear deep within our body in its eternal truth as a pure event, but the environmental crisis that we as Earthbound creatures bear deep within us. The signal of this 'wound' provides us with the experience that the Earth existed long before us, both at an ontic or 'rock' level and ontological or preindividual level, and that I was born to embody it in my being-on-Earth. I embody this pre-individual Earth as morendo in my being-in-the-Anthropocene as operationalization of Gestell, that calls for the constitution of a World as crescendo of a being-in-the-Anthropocene beyond Gestell.

Only from a scientistic perspective, this morendo and crescendo is understood in terms of quasi-causality however. While causality -including quasi-causality and also conditions for the possibility (Möglichkeitsbedingung) — concerns beings, the morendo-crescendo from the pre-individual to the individual concerns being, i.e., our being-in-the-Anthropocene. Morendo is not concealing as dying away, but being as dying away, living a dying life. 
I agree with Stiegler that this crescendo does no longer belong to endosomatic phusis but is exosomatically constituted as our being-in-the-Anthropocene, in which noetic tekhnè is at the same time Earthbound tekhnè (Zwier and Blok 2017). It remains open for future exchanges whether an eco-centric concept of being-in-default, substantiated by biomimetic technologies, can be of help in the conceptualization of noetic tekhnè (Blok 2017).

\section{IV}

I am hesitant to accept Stiegler's further argument that the assignment of the being-indefault of noetic tekhnè obligates to "make their (de-)fault come true ... as the absence of epoch, as the 'post-truth era', as the presence of Nothingness, as the ordeal of what remains hidden, of what does nothing but conceal" (10). On the one hand, why should we feel any obligation to make the default true, to re-present our being-in-default, except in case one adheres to the metaphysical truth as Rectitudo and Richtigkeit for which the ordeal of truth remains closed. On the other hand, we have to accept our human limits in the ordeal of what does nothing but conceal. The ordeal of what does nothing but conceal would lead to a philosophical variety of Cotard's syndrome. In a strange way, there seems to be a connection between the metaphysical focus on the eye and perception of the present (idein, eidos), Stiegler's obligation to make default true as re-presentation, and the being of an eye that sees and reflects but is disconnected from the one who sees in case of people who suffer from Cotard's syndrome and experience they are dead or do not exist. One can argue that being-in-default requires the Cotard syndrome in order to have access to the presence of the truth as "presence of Nothingness" (10). But the price Stiegler has to pay for this experience is death and despair, i.e. the end of his being-in-default. In this respect, the process of exosomatisation of World is a more fruitful way forward, as World provides the meaningful order in which any being-in-default remains connected to his or her being-in-default, and enables us to experience our being-in-default as being-on-Earth, in which each and every being-in-the-World, also our current being-in-the-Anthropocene, remains embedded. But this requires us to accept the limit of human experience. But then it is no longer possible to experience the inaccessibility of Ereignis as the hidden. This is the price we have to pay for the Ordeal of Truth.

Open Access This article is licensed under a Creative Commons Attribution 4.0 International License, which permits use, sharing, adaptation, distribution and reproduction in any medium or format, as long as you give appropriate credit to the original author(s) and the source, provide a link to the Creative Commons licence, and indicate if changes were made. The images or other third party material in this article are included in the article's Creative Commons licence, unless indicated otherwise in a credit line to the material. If material is not included in the article's Creative Commons licence and your intended use is not permitted by statutory regulation or exceeds the permitted use, you will need to obtain permission directly from the copyright holder. To view a copy of this licence, visit http://creativecommons.org/licenses/by/4.0/.

\section{References}

Blok, V. (2017). Earthing technology: Towards an eco-centric concept of biomimetic technologies in the anthropocene. Techne: Research in Philosophy and Technology, 21(2-3), 127-149. https://doi.org/10. 5840/techne201752363. 
Blok, V. (2019). Nothing else matters: Towards an ontological concept of the materiality of the earth in the age of global warming. Research in Phenomenology, 49, 65-87.

Blok, V. (2020a). Heidegger's concept of philosophical method. Innovating philosophy in the age of global warming. New York: Routledge.

Blok, V. (2020b). Beyond enmeshment: Critical reflections on the post-humanist position in the Anthropocene", Working paper.

Zwier, J., \& Blok, V. (2017). Saving earth encountering Heidegger's philosophy of technology in the anthropocene. Techne: Research in Philosophy and Technology, 21(2), 222-242.

Publisher's Note Springer Nature remains neutral with regard to jurisdictional claims in published maps and institutional affiliations.

Vincent Blok is associate professor in Philosophy and Ethics of Technology and Innovation at the Philosophy Group, Wageningen University (The Netherlands). In 2005 he received his PhD degree in philosophy at Leiden University with a specialization in philosophy of technology. Blok's research group is specialized in Business Ethics, Philosophy of Technology and Responsible Innovation. Together with six PhD candidates and four Post-docs, he is involved in several (European) research projects. His books include Ernst Jünger's Philosophy of Technology: Heidegger and the Poetics of the Anthropocene (Routledge, 2017) and Heidegger's Concept of Philosophical Method (Routledge, 2020). Blok published over hundred articles in high ranked philosophy journals like Environmental Values, Business Ethics Quarterly, Synthese and Philosophy \& Technology, and in multi-disciplinary journals like Journal of Cleaner Production, Public Understanding of Science and Journal of Responsible Innovation. See www.vincentblok.nlfor more information about his current research. 